УДК 808.5:792.028.3

DOI:

Анфіса Коленко, старший викладач кафедри сиенічної мови Київського національного університету театру, кіно і телебачення імені І.К. Карпенка-Карого

\title{
АНАЛІТИКО-СИНТЕТИЧНІ ВПРАВИ З ТЕКСТОМ ЯК ЗАСІБ УДОСКОНАЛЕННЯ МИСТЕЦТВА СЦЕНІЧНОЇ МОВИ
}

У статті розглянуто засоби формування професійно значущих якостей техніки мовлення майбутніх акторів театру $і$ кіно не як одноразовий акт, а як довготривалий проиес, який має інтегрований характер $i$ забезпечується усіма професійно зорієнтованими навчальними дисииплінами. Особливу роль автор відводить аналітико-синтетичним вправам з текстом у роботі над сценічною мовою. Запропоновані уривки віршованих, прозових та драматичних творів ілюструють різні аспекти роботи над текстом і можуть бути використані у роботі над удосконаленням навичок професійного мовлення акторів театру, кіно і телебачення у класі сиенічної мови.

Ключові слова: сценічна мова; аналітико-синтетичні вправи; партитура тексту; синтагматичне членування; мелодекламація; прийом “скелетування”.

Jim. 9.

Anfisa Kolenko, Senior Lecturer of the Stage Language Department Kyiv Ivan Karpenko-Kariy National Theatre Cinema and Television University

\section{ANALYTIC-SYNTHETIC TEXT EXERCISES AS MEANS OF IMPROVING SCENIC SPEECH DELIVERY SKILLS}

Present paper proposes the methods of forming professional scenic speech delivery skills in actors in the medium of theatre, cinema and television. It is emphasized that the methods discussed do not work by way of singular happening but are part of continuous practicing process with its multi-faceted nature and back-up from every other academic discipline within university framework.

Based on K. Stanislavskiy's laws of speech logic, the main emphasis in the methods proposed goes onto complex literary, linguistic and speech delivery analysis of text, which serves to form base for skills for delivering scenic speech in its ultimate meaning as word uttering.

The paper summarizes scholarly works dedicated to methods of teaching scenic speech, and goes further to propose a system of analytic-synthetic exercises with chief guideline-to find out which of the orthoepic (proper voice leading) and syntactic (phrasing and viewpoint making, punctuation marks such as comma, period, ellipsis, colon, semicolon, exclamation point, dash, inversion, omission, rupture) language means are most important for achieving desirable effect. Clarity of the actor's scenic speech can be improved by communicative situation-based training. According to the author of the paper, melodeclamation is another effective method of improving scenic speech delivery skills.

To gain the high level of scenic speech delivery skills, it is absolutely necessary for an actor to know: the sequence in which means of logical-emotional expressiveness of text are applied; ways of splitting up text into speech units; ways of determining logical and main emphases in accordance with melodics and tempo; ways of determining emotional load of the words emphasized; usage principles for extralinguistic means of expressiveness (pose, gestures, facial expressions); and to know how to prepare text for reading and analysis. All of these serve as groundwork for improving scenic speech delivery skills, as well as a way of elucidating the author's meaning.

Poetry, prose and drama works' excerpts provided in the paper serve to illustrate different aspects of working with text and may be put to good use when working on improving the actor's scenic speech delivery skills.

Keywords: scenic speech; analytic-synthetic exercises; musical score of text; syntagmatic split into units; melodeclamation; "skeletization" procedure.

П остановка проблеми. "Рецепція драматургічного твору відбувається через інформаційну поліфонію: читач/ глядач одномоментно отримує інформацію 3 шести-семи джерел: декорації, костюмів, реплік персонажів, їх жестів, міміки..” [4, 118]. Але чим більше увиразнюється експресивний зміст слова у контексті певної мовно-комунікативної ситуації, тим яскравішим і живішим виявляється персонаж. Сучасна театральна педагогіка України продовжує сповідувати засади, на яких будував свою “систему” К.Станіславський, розвивали корифеї українського театру - М. Кропивницький, М. Заньковецька, М. Садовський, П. Саксаганський, Л. Курбас. Ця основа залишається незмінною і сьогодні: первинна властивість мови - це дієвість. 


\section{АНАЛІТИКО-СИНТЕТИЧНІ ВПРАВИЗ ТЕКСТОМ ЯК ЗАСІБ УДОСКОНАЛЕННЯ МИСТЕЦТВАСЦЕНІЧНОӤ МОВИ}

Для іiі формування у нові часи потребуються нові педагогічні методи, технічні прийоми та засоби, які б грунтувалися на правді самого життя в роботі над акторською майстерністю, зокрема над сценічною мовою.

Аналіз основних досліджень і публікацій. Дослідники мистецтва сценічного мовлення (А.В. Бурлуцький, О.Б. Винар, Н.М. Баженов, I.І. Герц, А.О. Гладишева, М.О. Кнебель, І.О. Кусяк, О.А. Лавріненко, Т.В. Нечаєнко, А.Н. Петрова, Ю.В. Раденко, Н.В. Стадніченко, Р.А. Черкашин, М.О. Юдов та інші) звертають увагу на різні аспекти у формуванні сценічної мови.

На думку А.О. Гладишевої, сценічна мова $€$ своєрідним феноменом, одним 3 різновидів літературної мови, утвореним унаслідок активної взаємодії усної і писемної форм мовлення, злиття мови драматичних творів та театральних вистав $[2,5]$.

За словами М.О. Кнебель, “Драматическое искусство - искусство сложное, оно содержит в себе ряд составных частей. Но главным из них, непосредственно впечатляющим зрителя, воздействующим на него, является слово" $[3,3]$.

Водночас I.I. Герц та Т.В. Нечаєнко обгрунтовують методику роботи над сценічним мовленням, зазначаючи, що мовлення є засобом спілкування між людьми, передання власного досвіду іншим і збагачення їх (інших) досвідом $[1,124]$.

Разом 3 тим, відчувається дефіцит напрацювань науковців у галузі методики викладання сценічної мови у вищих мистецьких закладах освіти. Мета статті - висвітлити набутий практичний досвід роботи над текстом 3 метою удосконалення навичок сценічної мови як словесної дії.

Виклад основного матеріалу. Відповідно до виокремлених К. Станіславським законів логіки мови (закон словесної дії, контексту і підтексту, закон перспективи і закон нового поняття, закон створення і відтворення послідовної лінії бачень, закон порівняння і протиставлення...) основним у творчості актора $\epsilon$ виявлення суті твору (надзавдання) і втілення її в ролі (наскрізна дія). На думку К.С. Станіславського, сценічна дія має бути внутрішньо обгрунтованою, логічною, послідовною і можливою в дійсності [9].

“Відкриті К. Станіславським закони логіки мовлення диктують правила розміщення пауз, логічних наголосів, інтонування мови у реченні та допомагають майбутньому актору знаходити правильне рішення у роботі над роллю та стимулюють його до самостійної творчості" [8, 143].
На жаль, сьогодні можемо спостерігати у мові актора порушення норм законів логічного мовлення, а саме: наголошування, акцентуація кожного слова в реченні без виправданих на те причин; наголос на певному слові без урахування попередньої думки, контексту; застосування правил наголошування в рамках окремого закінченого речення, а не всього тексту; наголошування службових частин мови або слів, неважливих за думкою, дією. Неправильно ж визначена логічна пауза порушує логіку мислення, тобто спотворює головну думку, може надавати реченню іншого, а інколи і протилежного змісту.

Саме це і підказує методику діяльності викладача в роботі над сценічною мовою, яка полягає у послідовності дій: від спостереження через аналіз до живого мовлення. При такому підході забезпечується свідоме сприймання тексту твору i, відповідно, усвідомлена його інтерпретація на сцені, насамперед, через словесну дію. В основі такого підходу літературознавчий, лінгвістичний і виконавський аналіз тексту в їх єдності, взаємопроникненні і взаємовпливі.

Для того, щоб мовлення стало дієвим, воно повинно бути виразним. "Виразність - це така комунікативна якість, завдяки якій здійснюється вплив на емоції та почуття аудиторії... Виразність розвивається на основі тренінгів, власних творів, спостережень над мовленням різних соціальних груп, аналітичного читання художньої літератури" $[7,100]$.

До тренінгових відносимо вправи на орфоепічний аналіз прозових та драматичних текстів, віршів; логічний аналіз текстів; лінгвістичний аналіз художніх текстів; читання текстів синхронно 3 жестами, рухом або у статиці.

Для вироблення навичок відчуття паузи і вміння відтворити іiі на сцені пропонуємо різноманітні вправи: читання тексту за схемами речень 3 різним інтонаційним наповненням відповідно до змісту; створення власних висловлювань відповідно до поданих інтонаційних схем тощо.

“Засобами відтворення логічного змісту є членування тексту на частини, здійснення логічних наголосів у межах цих частин і в межах усього уривка, зміна темпу промовляння окремих синтагм, мовних тактів" [5, 138]. Завдання викладача сценічної мови - навчити студентів “відчувати” смислові частини речення, тексту (синтагми). Для прикладу:

- Мати Божа! // увесь будинок зворухнувся: // білити, // мити, // прибирати! ... // Панночки 


\section{АНАЛТИКО-СИНТЕТИЧНІ ВПРАВИ З ТЕКСТОМ ЯК ЗАСІБУДОСКОНАЛЕННЯ МИСТЕЦТВАСЦЕНІЧНОЇ МОВИ}

сподіваємось! // панночка буде! // Стара пані // немов одужала: // коливає з кімнати до кімнати, / // виглядає у кожне віконце на шлях /// і нас // туряє за село // дивитись, // чи не їде панночка (Марко Вовчок).

Синтагматичне членування речення (тексту) співвідноситься із визначенням тактів. Мовний такт - це синтаксичне ціле, що може об'єднувати групу підмета, групу присудка, групу обставинних слів і т.д. Виділення слів у мовному такті досягається різними засобами: голосовим підсиленням, підвищенням тону або розтягуванням, або їх комбінацією.

Найпростішим прийомом, який наближає актора до мети - словесного впливу на партнера, допомагає організувати потрібне бачення і знайти шлях до передачі справжнього почуття, - $\epsilon$ визначення дієвого центру фрази/речення, вимовляння фрази гранично точно за законами мови, дотримуючись знаків пунктуації. Цьому сприяє відповідна розмітка тексту-розписування партитури. Правильно розписана партитура - це надійний помічник педагога і майбутнього актора під час читання твору. Звільнення тексту від слів, які лише доповнюють його основний смисл, можна за допомогою прийому скелетування.

До прийому скелетування доцільно вдаватися при знаходженні слів, які вимагають логічних акцентів і неодмінно мають бути виділеними. Наприклад:

Вечірня вулиця наче дно річки, по якому ти йдеш, ідеш по грузькому піску, а з обох боків над тобою здибилися білі пахучі хвилі.

Скелет: Вулиця - дно річки, а $з$ обох боків хвилі.

Якщо логічний центр перемістити зі слова вулиця на слово вечірня, справжній зміст фрази буде втрачений.

У системі засобів, якими посилюється образність, виражальна цінність мовлення, важливу роль відіграють синтаксичні мовні засоби, зокрема інтонаційні фігури знаків пунктуації: кома, крапка, три крапки, двокрапка, крапка 3 комою, знак оклику, тире. Вправи на виявлення “на слух" речень - розповідних, стверджувальни, питальних, спонукальних, окличних - дають можливість студентам усвідомити авторську логіку думки і відтворити iii в усному мовленні. Наприклад:

Ярослав (нетерпляче):

А там весна ... а там ... Яка нудота

Оці слова нікчемні і пусті,

Що їх за мудрість продають в житті!

Мовчи, монаше! Не дратуй словами.

Де ж той Гаральд? Невже перед дверима
Його повинен ждати руський князь!

Гей, хто там $€$ ? (до Слов'яти)

Хто дав тобі наказ

Сурмити збір, коли нема Гаральда?

Слав'ята:

Княгиня, княже. Власне, син Рангвальда.

Ярослав (гнівно):

Це змова, щоб мою понизить честь!

Де Інгігерда? (I. Кочерга, “Ярослав мудрици”).

Особливий стан напруження і схвильованості автор може передавати через еліпсис (грецьке. elleipsis - пропуск, випадіння) - стилістична фігура, що полягає в опущенні певного члена речення чи словосполучення, які легко відновлюються за змістом поетичного мовлення. Вживається для досягнення динамічності і стислості вираження думки та напруженості дії, відрізняючись тим від обірваної фрази (апосіопези), власне, вмовчування $[6,232]$.

- Чули?

- Та чули.

- Ну, що ж?

- Як люди?

- Бастують.

- Коли бастують, то й ми пристанемо...

(М. Коцюбинський)

Важливо навчити майбутніх акторів відчувати різницю між еліпсисом і обривом, що теж побудований на пропуску, який зумовлений глибокою внутрішньою схвильованістю. 3 цією метою доцільно зробити порівняльний аналіз попереднього і наступного текстів:

- Олександро Петрівно, дозвольте мені втопитися в дворі в колодязі! - промовила несміливо дівчина.

- Що?!

- Дозвольте мені втопитися...

Олександра Петрівна встала, підійшла до неї ближче і глянула на неї.

- Ти хвора?

- Hi.

- Дак що ти таке кажеш?

- Я кажу ... Я не хочу тут жити ... Я хочу втопитися ...Дозвольте мені ...

(Б. Грінченко, “Дзвоник”).

Аналітико-синтетична робота 3 текстами різного змісту і психологічного навантаження сприяе усвідомленню ролі синтаксичних фігур (інверсія, для створення настрою персонажа, стимулює прагнення досягти найвищого рівня його передачі глядачеві/слухачеві у власній, але близькій до авторського бачення, інтерпретації:

Реве та стогне Дніпр широкий, (иирокий Дніпр реве та стогне) 


\section{АНАЛТИКО-СИНТЕТИЧНІ ВПРАВИ З ТЕКСТОМ ЯК ЗАСІБУДОСКОНАЛЕННЯ МИСТЕЦТВАСЦЕНІЧНОЇ МОВИ}

Сердитий вітер завива...
(сердитий вітер завива)
Додолу верби гне високі,
верби гне додолу)
Горами хвилю підійма (Т.Шевченко) (підійма
хвилю горами)
Або:
Судьба царів земних в руці господній, Судьба
земних иарів в господній руиі,
І не страшний в апрілі божий сніг. I не
страшний в апрілі божсий сніг.
Бо не к Різдву іде, а к Великодню, Бо іде не к
Різдву, а к Великодню,
І скоро вже прийде він на поріг. І скоро вже
він прийде на поріг.
Розтане сніг, а з ним твої турботи. Сніг
розтане, а з ним твої турботи.
Та і дочку відпустиш не на вік. Та і відпустиш
дочку не на вік.

(I. Кочерга “Ярослав Мудрий”)

Інверсія у драматичних творах використовується для передачі специфіки розмовного мовлення. Це легко простежується при аналізі уривка з п’єси “Наталка Полтавка" I. Котляревського. Наприклад:

Терпелиха: Лучче була б я умерла: не терпіла б такої біди, а більше через твою непокорність.

Наталка: (оставляє роботу) Через мою непокорність ви біду терпите? Мамо!

Терпелиха: Аякже? Скільки хороших людей сваталось за тебе - розумних, зажиточних і чесних, а ти всім одказала; скажи, в яку надежду?

Працюючи над цими уривками, майбутні актори виробляють відчуття ритму і логічного наголосу, бо, “зазвичай, він падає на початок та кінець фрази. Тому ці місця займають слова, що несуть на собі основний зміст сказаного" [4,306].

Визначити місце логічного наголосу допомагає правило про порівняння: при порівнянні наголос падає на той предмет (його умовно називають другим членом порівняння), з яким порівнюється те, про що йде мова” $[5,141]$. Якщо в реченні $\epsilon$ слова "наче, неначе, мов, немов, як" - перед ними або після них обов'язково робиться пауза:

Сім'я ся вбога за своє нечестя.

Тепер ся жінка, мов вівця покірна,

Бо злидні стисли... Та душа в ній вовча...

Господь іï скарає, як Сапфіру,

Ананієву жінку нечестиву,

що покривала чоловіка гріх... (Леся Українка, “У пущі”)

Як тополя, стала в полі
При битій дорозі;

Як роса та до схід сонця,

Покапали сльози. (Т. Шевченко)

Не менш важливим є прийом підставлення слів, який допомагає в проясненні логічного смислу фрази, отже, знаходженні логічного наголосу: Жадаєте багато, а не дістанете нічого, то весь Борислав вас висміс (I. Франко) “Досить після сполучника $a$ вставити ще один якщзо або коли, як фраза буде осмислена й інтонація почне підніматися до слова нічого, яке знаходиться в інтонаційному переломі" [5, 144].

Має свою інтерпретацію і закон протиставлення. Якщо в тексті є протиставлення (явне чи приховане), то наголошуємо ті слова, завдяки яким це протиставлення оформляється. При цьому розповідне речення вимагає підвищення тону на першому з тих слів, що протиставляються, і зниження тону - на другому [5].

Ой ти, дівчино, з горіха зерня,...

Чом твої устонька - тиха молитва,

А твоє серце гостре, як бритва? (І. Франко)

Або у Т. Шевченка:

Не нам на прю $з$ тобою стати,

Не нам діла твої судить

Нам тільки плакать, плакать, плакать...

I хліб насущний замісить ...

При детальній аналітичній роботі над партитурою тексту звертаємо увагу на специфіку наголошування у тексті окремих частин мови. Наголошення займенника, відповідно до правила про нове поняття, майже виключається, оскільки займенником найчастіше визначаються поняття, які були вже названі (виняток: займенник наголошується при протиставленні, або коли можна поставити запитання хто? і стоїть після прикметника).

Мій народе!

У сади твої, залиті сонцем.

не повернуться ночі страшні.

Я твій атом, в твоїй я орбіті, а

І другої не треба мені. (В.Сосюра)

Дуже часто у драматичних творах наголошуються дієслова, при цьому частіше логічний наголос буває наприкінці мовного такту, а у групових найменуваннях (при переліку) наголошується останнє слово, якщо енергія мовлення підвищується; і навпаки - перше, якщо енергія спадає.

Безродний: Ви любили багато і все оддали тій любові; а любов - найбільша на землі сила, найвища сила й на небі: вона ніколи марно не гине; вона - і джерело, і весь розум життя! 


\section{АНАЛТИКО-СИНТЕТИЧНІ ВПРАВИ З ТЕКСТОМ ЯКЗАСІБУДОСКОНАЛЕННЯ МИСТЕЦТВАСЦЕНІЧНОЇ МОВИ}

Лучицька (усміхається щасливо): Так, так... Ви примирили мене... розважили...

Безродний: Та ще й жити будемо... Он і я, який дохлий, а ще сподіваюсь потрудитись... Вірте, вірте!

Лучицька: Ох, коли б! Як мені хочеться жити, серцем радіти... Господи, не вкороти мого віку! (становиться на коліна) Пошли мені хоч хвилинку щастя... Я не зазнала його... Я нікому зла не вчинила!.. (М. Старицький, “Талан”)

Студенти зауважують, що завжди наголошуються однорідні члени речення, які мають різні поняття.

Оскільки логічний наголос - це фактор живого мовлення, особливу роль у ньому грає інтонація. Компоненти інтонації - мелодика, сила звуку, швидкість, інтенсивність, тембр (емоційне забарвлення), чіткість вимови. Для вироблення власної версифікаційної інтонації майбутнім акторам доцільно визначати ритмомелодику творів чи їх уривків і підбирати до них музичний супровід, тобто застосовувати мелодекламацію.

Мелодекламація (грецьк. melos - пісня та лат. declamation - вправа в ораторському мистецтві) - читання віршів та прозових творів (уривків) у музичному супроводі [6,447]. Музичні композиції до аналізованих текстів можуть підбирати і самі здобувачі вищої мистецької освіти. Мелодекламація сприяє виробленню відчуття ритму у мові. Художні твори можуть передавати різні ритмічні відтінки: пісню, романс, коломийку тощо. В танцювальному ритмі написані Шевченкові “Утоптала стежечку”, “Якби мені черевики" та інші.

Якби мені черевики,

То пішла б я на музики.

Горенько моє!

Черевиків немає,

А музика грає, грає.

Жалю завдає!....

Студентам пропонується визначити ритм твору i, промовляючи текст, “протанцювати” його. Цей прийом сприяє гармонізації голосу і рухів тіла. Виконуючи такі вправи, майбутні актори виробляють навички словесної дії у будь-якій мовленнєвій ситуації. Для цього підбираємо твори з “ритмом” вальсу, гопака, коломийки, польки, рокен-ролу тощо. Для прикладу:

1. (у ритмі вальсу) - "Коли було заговорить, то усе так звичайно (як звичай велить), розумно, так наче сопілочка заграє стиха. Що тільки б їі й слухав..." (Г. Квітка-Основ'яненко, “Маруся”).

2. (у ритмі коломийки) - "Білолиця, гарна й весела, а прудка. Як зайчик; і в хаті, й надворі в’ється, порядкує, господарює, і співає, і сміється, аж геть чутно їі голосок дзвенячий” (Марко Вовчок, "Горпина").

3. (у ритмі тяжкого року) - Не чорна хмара 3-за синього моря наступала, то виступала Мотря з Карпом з-за своєї хати до тину. Не сиза хмара над дібровою вставала, то наближалася до тину стара видроока Кайдашиха. Дві сім"ї, як дві чорні хмари, наближалися одна до другої, сумно й понуро (І. Нечуй-Левицький, “Кайдашева сім'я”).

Висновки. Отже, для досягнення високої майстерності слова необхідно: знати послідовність застосування засобів логіко-емоційної виразності тексту; способи членування тексту на мовні такти, шляхи визначення логічних і основних наголосів уєдності з мелодикою і темпом; способи визначення емоційної функції наголошуваних слів; уміти підготувати художній твір до читання й аналізу. Лінгвістичний та логічний аналіз тексту ролі сприяє усвідомленню змісту висловлюваної думки, закладеної автором у репліки персонажів. Але навіть найдетальніший логіко-стилістичний та художньо-лінгвістичний аналізи тексту ролі не можуть замінити словесної дії. Вони є лише початком, фундаментом роботи над технікою мовлення, засобом виявлення авторського задуму.

Подальші дослідження полягають у визначенні ефективних методів та прийомів комплексного поєднання вербальних і невербальних компонентів 3 метою досягнення високої майстерності володіння сценічною мовою як словесною дією.

\section{ЛІТЕРАТУРА}

1. Герц І. І., Нечаєнко Т. В. Роль зовнішньої техніки в процесі оволодіння сценічним мовленням. Альманах наукового товариства “Афіна” кафедри культурології та музеєзнавства Рівненського держ. гуманітарного ун-ту. Актуальні питання культурології. 2016. Вип. 16. С. $123-128$.

2. Гладишева А. О. Сценічна мова. Дикційна та орфоепічна нормативність. Навч. посібник. Київ, 2007. 270 с.

3. Кнебель М., “О действенном анализе пьесы и роли" Учебное пособие. 5-е изд., стер. Издательство “Лань”, 2016. 204 с. URL: http:// teatre.com.ua/upload/all/lib/Slov-drama.pdf

4. Кочан I.M. Лінгвістичний аналіз тексту: Навч. посіб. 2-ге вид., перероб. і доп. Київ: Знання, $2008.423 \mathrm{c}$.

5. Кравцова I.А., Шпачук Л.Р. Основи культури і техніки мовлення: навчальний посібник. Кривий Ріг: КПІ ДВНЗ “КНУ”, 2013. 294 с.

6. Гром’як,Р.Т., Ковалів Ю.І. таін. Літературознавчий 
словник-довідник. Київ: ВЦ “Академія”, 1997. $752 \mathrm{c}$.

7. Сагач Г. М. Золотослів: навчальний посібник для середніх і вищих навчальних закладів. Київ: "Райдуга", 1993. 378 с.

8. Стадніченко Н.В. Формування професійного спілкування майбутніх акторів засобами сценічного мовлення. Вісник Запорізького національного університету, Серія Педагогічні науки, 2 (20). 2013. С. 140-145.

9. Станиславский К. С. Работа актера над собой в творческом процессе переживания, 2015. URL: https://www.yakaboo.ua/rabota-aktera-nadsoboj-v-tvorcheskom-processe-perezhivanija1795498.html

\section{REFERENCES}

1. Hertz, I. I. \& Nechayenko, T.V. (2016). Rol zovnishnyoyi tekhniky v protsesi ovolodinnya stsenichnym movlennyam [Role of speech delivery technique in the process of mastering scenic speech]. Almanac of the "Aphina" scholarly society, Department of cultural and museum studies, Rivne national humanities university. Topical issues in cultural studies. Iss. 16, pp. 123-128. [in Ukrainian].

2. Hladysheva, A. O. (2007). Stsenichna mova. Dyktsiyna ta orphoepichna normatyvnist [Scenic speech. Enunciation and rules of pronunciation]. Textbook. Kyiv, 270 p. [in Ukrainian].

3. Knebel, M. (2016). O deystvennom analizye pyesy i roli [On effective analysis of a play and character in it]. Textbook. $5^{\text {th }}$ impression. Lan' publishing house, 204 p. Available at: http:// teatre.com.ua/upload/all/lib/Slov-drama.pdf [in Russian].

4. Kochan, I. M. (2008). Linhvistychnyy analiz tekstu [Linguistic analysis of text]. Textbook, 2nd edition, revised and enlarged. Kyiv: Znannya, 423 p. [in Ukrainian].

5. Kravtsova, I. A. \& Shpachuk, L. R. (2013). Osnovy kultury i tekhniky movlennya [Basics for speech culture and speech delivery technique]. Textbook. Kryvyi Rih: KPI DVNZ "KNU”, 294 p. [in Ukrainian].

6. Hromyak, R. T. \& Kovaliv, Yu. I. et al. (1997). Literaturoznavchyy slovnyk-dovidnyk [Dictionary of literary criticism]. Kyiv: "Akademiya" publishing house, 378 p. [in Ukrainian].

7. Sahach, H. M. (1993). Zolotosliv [Mouth of gold]. Textbook. Kyiv: Rayduha, 378 p. [in Ukrainian].

8. Stadnichenko, N. V. (2013). Formuvannya profesiynoho spilkuvannya maybutnikh aktoriv zasobamy stsenichnoho movlennya [Shaping professional communication skills in future actors by means of scenic speech]. Herald of Zaporizhzhya national university, pedagogical studies section, 2 (20), pp. 140-145. [in Ukrainian].

9. Stanislavskyy, K. S. (2015). Rabota aktyora nad soboy $\mathrm{v}$ tvorcheskom processe perezhyvaniya [Actor working on his/her technique in the process of creative re-living his/her character]. Available at: https://www.yakaboo.ua/rabota-aktera-nad-soboj-vtvorcheskom-processe-perezhivanija-1795498.html [in Russian].

Стаття надійшла до редакції 30.01.2019

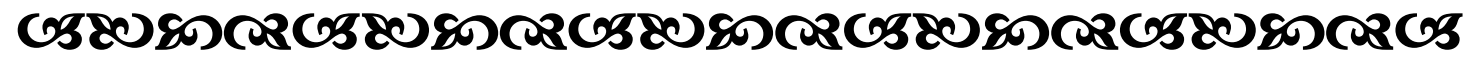

"Корисним для себе ( $і$ для суспільства) буде тільки той, хто пізнав свою природу. ТТод людина розуміє свою місію. Своє поқликання на землі й виробляє для себе спосіб життя, в основі яқого лежить “споріднена праця". ТІільки так людина може самоствердитися і самореалізуватися, а значить стати щасливою”.

Тригорій Сқоворода уқраӥнський просвітитель-гуманіст, бөілософб, поет, педагог

“Навчання ніқоли не вичерпує розум”.

Леонардо да Вінчі видатний італійський вчений, дослідник,

"Успіх однієї відважної людини завжди спонуқає до завзяття й мужності иіле покоління".

Оноре де Бальзак франиузькии романіст і драматург

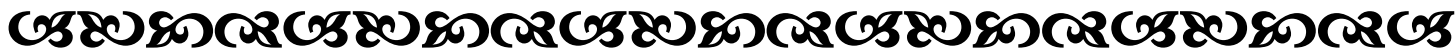

